\title{
First Language Acquisition: A Case Study of Language Disorders in Children (3 Years Old)
}

\author{
Elvrin Septyanti, Charlina Charlina \\ Universitas Riau \\ elvrin.septyanti@lecturer.unri.ac.id
}

\begin{abstract}
This study aimed to describe the first language acquisition of 3 years old children who experience language disorders in the category of language disorders experienced and factors causing language disorders. The object of this study was a 3-year-old boy named Arjuna El Sharif Uwaish. The method used was diary and observation. The research design used was longitudinal studies. This study was conducted for 12 months and is sustainable. Techniques of data collection was done through techniques refer, record, and record. This technique includes activities viewing the daily activities of children while recording sounds resembling words and then transcribe the recording in the form of writing. As for the conclusion of data, there are 22 phonetic sounds from the phonological aspects, there are 85 morphemes (both whole and partial morphemes) from the morphological aspect, and from the syntactic aspect, Arjuna only able to produce 11 sentences either major or minor. Based on the data analysis, it was concluded that Arjuna case including children who suffer from language disorder of subcortical motor affasia language disorder. The imperfect child produces speech in the form of a word even though he understands what the other person is talking about, the speaker's command, the other's request, and the like. The cause of speech delay is caused due to environmental factors so it needs to be followed up through medical assistance, such as specialist child-grown doctor, psychologist, and therapist.
\end{abstract}

Keywords--first language acquisition, speech delay, language disorder

\section{INTRODUCTION}

In the language conscience hypothesis, the acquisition of the first true language can be naturally acquired humanity since birth because humans have been equipped with a language acquisition device (LAD) tool. LAD is a special tool that allows children to acquire their native language by themselves. The LAD forms one of the formal grammar as its output (Chomsky and Miller in Chaer, 2003, p. 169). The child-speaking process begins in the cooing phase. This phase begins at the age of 6 weeks. Currently, phonological language acquisition of the language appears. The child produces consonant or vocal sounds (Dardjowidjojo, 2010, p. 244). Next, the children will undergo babling phase. This phase begins at 6 months of age. Arsanti (2014, p. 27) added,

The chatter begins with a consonant and is followed by a vowel. The first consonant to come out is bilabial resistor and nasal bilabial. The vowel is /a/. Thus, the structure is CV. Another feature of the babble is that CV is repeated into C1V1C1V1. papapa mamama bababa. The next consonant sounds gradually changed into dadi, dida, tita, tati, mama, mami, etc.

Then the alveolar and velar will appear after the child controls the bilabial consonant. Africtive sound / $\mathrm{tZ} / \mathrm{and} / \mathrm{dZ} /$ is dominated later, about four years old. Here is a consonant table in Indonesian that should be mastered. 
Table 1.

Indonesian Consonants

\begin{tabular}{|c|c|c|c|c|c|c|c|c|c|c|c|}
\hline & Bilabial & $\begin{array}{l}\text { Labio- } \\
\text { dental }\end{array}$ & Dental & Alveotar & $\begin{array}{l}\text { Pos: } \\
\text { Aneolar }\end{array}$ & $\begin{array}{l}\text { Retro- } \\
\text { neks }\end{array}$ & Palatal & Velar & Unvilar & Faringel & Glotal \\
\hline Letupan & p b & & & $t d$ & & t d & $c_{j}$ & $\mathrm{~kg}$ & & & $?$ \\
\hline Nasal & m & & & $\mathbf{n}$ & & & $\mathrm{n}$ & פ & & & \\
\hline Trit & & & & $\mathbf{r}$ & & & & & & & \\
\hline Frikatif & & f v & & s z & & & & & & h & \\
\hline Alrikat & & & & & & & $\varsigma j$ & & & & \\
\hline Aproksiman & $w$ & & & & & & $\mathbf{j}$ & & & & \\
\hline $\begin{array}{l}\text { Aproksiman } \\
\text { Lateral }\end{array}$ & & & & 1 & & & & & & & \\
\hline
\end{tabular}

Source: Kushartanti (2005, p. 41)

This year's benchmark is very relative. Size should not be calendar year, but it should be a neurobiological year, meaning at the stage of neurobiological development where a child can utter certain sounds. In relation to the case, L. Nicolosi, E. Harryman, J. Kresheck (2004) calcified the development of phonetic sounds that should be controlled by children according to the child's age.

Table 2 .

Speech Sound Development

From The Goldman Fistone Test of Articulation 2 from 2000

\begin{tabular}{clcc}
\hline Age & \multicolumn{1}{c}{ Initial Sounds } & Medial Sounds & Final Sounds \\
\hline 2 years & $/ \mathrm{b} / . / \mathrm{d} /, / \mathrm{h} /, / \mathrm{m} /, / \mathrm{n} /, / \mathrm{p} /$ & $/ \mathrm{m} /, / \mathrm{b} /, / \mathrm{m} /$ & $/ \mathrm{m} /, / \mathrm{p} /$ \\
\hline 3 years & $/ \mathrm{f} /, / \mathrm{g} /, / \mathrm{k} /, / \mathrm{t} /, / \mathrm{w} /$ & $/ \mathrm{f} /, / \mathrm{g} /, / \mathrm{k} /, / \mathrm{ng} /, / \mathrm{p} /, / \mathrm{t} /$ & $/ \mathrm{b} /, / \mathrm{d} /, / \mathrm{g} /, / \mathrm{k} /, / \mathrm{n} /, / \mathrm{t} /$ \\
\hline 4 years & $/ \mathrm{kw} /$ & $/ \mathrm{d} /$ & $/ \mathrm{f} /$ \\
\hline 5 years & $/ \mathrm{ch} /, \mathrm{j} /, / \mathrm{l} /, / \mathrm{s} /, / \mathrm{sh} /, / \mathrm{bl} /, / \mathrm{y} /$ & $/ \mathrm{ch} /, / \mathrm{j} /, / \mathrm{l} /, / \mathrm{s} /, / \mathrm{sh} /, / \mathrm{z} /$ & $/ \mathrm{l} /, / \mathrm{ng} /, / \mathrm{ch} /, / \mathrm{j} /, / \mathrm{s} /$, \\
& & & $/ \mathrm{z} /, / \mathrm{sh} /, / \mathrm{r} /, / \mathrm{v} /$ \\
\hline 6 years & $/ \mathrm{r} /, / \mathrm{v} /, / \mathrm{br} /, / \mathrm{dr} /, / \mathrm{fl} /, / \mathrm{fr} /, / \mathrm{gl} /$, & $/ \mathrm{r} /, / \mathrm{v} /$ & \\
& $/ \mathrm{gr} /, / \mathrm{kl} /, \mathrm{kr} /, / \mathrm{p} /, / \mathrm{st} /, / \mathrm{tr} /$ & & $/ \mathrm{th} /$ \\
\hline 7 years & $/ \mathrm{z} /, / \mathrm{sl} /, / \mathrm{sp} /, / \mathrm{sw} /, / \mathrm{th} /$ & $/ \mathrm{th} /$ & \\
\hline
\end{tabular}

This table is the age at which $85 \%$ of the GFTA 2 standardization sample correctly produced the consonant and consonant cluster sounds.

At a later stage, children will say a word for up to two words or more. The first word tends to begin at the age of 1 year in the western child. However, Dardjowidjojo (2010, p. 245) states that Indonesian children tend to produce the word from the age of 17 months. This statement is customized based on his research on "Echa" for a period of 5 years. Completing the above statement, Barrett in Gleason and Ratner (1998, p. 358) states "Children begin to produce recognizable words of their language at about 1 year of age. By 18 to 20 months, they typically hav acquired approximately 50 words, and by age 2 , an average chiled knows 200--300 words".

In general, children 17 to 20 months have mastered 50 words. Words that are said to be identical to the names, limbs, objects, pets, activities, and or toys that are around the child. Children aged 1.5 to 2 years are able to mention greeting parents [mama], [papa]. Animals for example imitate animal sounds and name animals, such as [cats], [chickens], [birds]. Mention of the name of the toy, such as [bicycle], [car] or any of the names of objects in the house or neighborhood, such as [key], [milk], [cup], [plate], [clothes], [bajung] etc. Furthermore, daily activities of children, such as [bobo '], [eating], [bathing], [drinking], [play]. Even dr. Denny Sigarlaki, Sp.A., M.Sc. As one of the specialist pediatricians grows and develops children at Eka Hospital Hospital Pekanbaru reveals $<2$ years old children are able to identify and names of body parts, such as [eye], [mouth], [hair].

In this phase, the child experiences the acquisition of the Syntactic field. The child starts by speaking a word (or a part of the word). This word, for the child is actually a full sentence, but because he has not been able to say more than one word, he only takes one word of the whole sentence is called One Word Utterance. The child does not just choose that 
word; he will choose a word that provides new information. The child already has knowledge of old information versus new information. Sentences are spoken to provide new information to the listener (Arsanti, 2014, p. 37).

Normally, children can experience a reasonable process in language acquisition. However, there are also some cases in children who experience speech delay from the age they should be. For example "Echa" grandson Soenjono Dardjowodjojo at the age of 18 months mengujarkan word bicycle with speech [da]. Some words are said to be the final fragment of the word he or she heard. Dardjowidjojo caused that the delay of speech which is also experienced by other Indonesian children is influenced by the vocabulary factor of Indonesian language mostly polisilabik. The child must first analyze the accepted syllable to determine which tribe will be taken (Dardjowidjojo, 2010, p. 245). However, the development of Echa language is still quite normal. At the age of 20 months, Echa has been able to produce 2 words of speech, such as / clay tuputupu / 'see butterfly', / etching mimic / 'Echa asking for mimic', / etching nani / 'Echa want to sing', / eyang tsini / ' Grandmother, come here! '(Dardjowidjojo in Dardjowidjojo, 2010, p. 248--249).

Another case was also found by Arjuna El Sharif Uwaish. 24-month-old child of Palembang descent who live in Pekanbaru. In daily Arjuna addressed Juna using Indonesian language as a means of communicating with both parents. Juna only lives with his father and mother. Everyday, Juna plays with a nanny when mom and dad work. At the age of 24 months, Juna has not mastered the vocabulary that should have existed in children at his age. Juna used to communicate through cues. Unlike the other children, Juna only produces the sound of words that have no meaning. Until the age of 24 months, Juna can only spell the word [ouch] correctly and have meaning. The rest, still babble and sounds that are unstructured and meaningless, such as [jejeba], [biabi], [mi], [orangelelele'lidah being played]. Cases of speech delay are dominated by boys. Cheuk in Cummings (2010, p. 86) states that 75, $2 \%$ of boys under 5 years are found to have cases of Specific Language Impairment (SLI). SLI includes language / speech delay, speech language disorder, language / speech impairment, childhood aphasia, developmental dysphasia, language development and language learning disability. Consequently, "Children with SLI aged three to six years had significantly higher rates in delivering unadulterated responses during interacting with adults than children 3 to 5 years of normal language development" (Cummings , 2010, p.. $88)$.

In line with previous statements, Spiliotopoulo (2009, p. 5-6) explains that Expressive Language Disorder or ELD is largely a childhood disorder that affects more boys than girls (American Psychiatric Association, 2000). This condition illustrates that the child does not have the ability to express thoughts and feelings with the use of words even though the child's chronological age should allow him to do so. A child with ELD can understand the language very well but can not communicate (Johnson \& Beitchman). In other words, the child has difficulty remembering words and expressing them. ELD and Behavior connect what he wants to say. In fact, children's speaking skills may be similar to those of younger children.

The lateness of speech experienced indicates that the interruption of language skills. In contrast to previous statements that speech delays are generally caused due to factors of syllabic analysis experienced by the child. This case is different because at that age there should not be 1 word that can be said. The normal human brain function and speech tool, certainly can speak well. A good language is the occurrence of a combination between two processes both productive (encoding) and receptive (decode) processes. Before humans speak for communication activities, the listener as a language tester will receive meaningful language codes that will be conveyed through his articulation tools. Furthermore, the production process ie the language process to be delivered is designed. Decode and encoding process integrated with the transmission process. This process moves and transmits codes that comprise human speech. When the decoding process, the transmission process, and the encoding process take place well, the language process will produce good results. Not so if one of the processes that are supposed to happen is interrupted. In this case, Cummings (2008, p. 283) found that children with language disorders had a family who also suffered from speech, reading disorders and language disorders compared with normal-developing children. However, language disorders are also influenced by this.

Suroso, Eko (2016, p. 115-117) explains that there are four factors that influence the language development of children, (1) health factors, (2) intelligence factors, (3) family socioeconomic factors, and (4) sex factors. In addition, language disorders can result from 2 factors, namely (1) medical factors and (2) social environmental factors (Chaer, 2010. p. 148). Sidhartha in Chaer (2010, p. 148) states medically, the language disorder can be divided into three groups, namely (1) speech disorders, (2) language disorders, and (3) thinking disorders.

Speech disorders are divided into 3, inter alia, interference with the mechanisms of speech such as a) pulmonary factors such as lungs, b) disturbances due to laryngeal or vocal cords, c) lingual disorders such as canker sores, and d) impairment due to resonance or nasal voice. The second speech disorder is a multifactorial disorder, such as talking haphazardly, talking propulsively in people with Parkinson's, speaking mutism or being silent. Third, psychogenic speech disorders, such as spoiled speaking, speaking of wood, speaking stuttering, and talkative speech. 
Language disorder. Sensory motor and sensory affasia. In general, motor fecundity is imprinted on the surface layer of the broca area or also in the Broca and Wernicke areas. This aphasia consists of three kinds, namely (1) cortical motor afasia, the sufferer understands spoken and written language but cannot produce words to express the content of the mind, (2) subcortical motor affasia, tend not to be able to utter words. The type of sound produced is like a whistle. However, the notion of verbal and visual language is not disturbed and visual expression is running normally. (3) transcortical motor affasia, the patient has disturbed the relationship between the Broca and Wernicke areas. The sufferer is not the same as the one heard or ordered. For example if asked, this pen who? The answer that is being asked is this. Another affasia is the sensory affasia losing the notion of spoken and written language.

\section{METHODS}

This research was case study research with object of child research 36 month named Arjuna El Syarif Uwaish. The design of this research was longitudinal studies. This study lasted 12 months (March 2017 until March 2018). The method used was a diary and observation. Data collection technique was through the activities of recording speech and behavior of children when said, both visually and auditorially. Based on the data collected, the data were analyzed by transcribing procedures and observing the visual form. Further, data processed to find its conclusions.

\section{FINDING AND DISCUSSION}

This research analyzes 3 aspects of language acquisition. They are phonological acquisition, morphological acquisition, and syntactic acquisition at 3 year olds. Phonological acquisition observes letters that have been mastered. Whether the application is in the beginning, middle, and end of the word and is associated with the child's age. On the acquisition of morphology observed the type of word and the form of the word that has been mastered by 3 years old. Furthermore, the acquisition of syntax only observes the minor and the mayor who has mastered 3-year-olds who have a language disorder.

\section{Acquisition of Phonology}

At age 3, Juna has earned some phonetic sounds both vocal and consonant. Vocal sounds /a/, / i/, /u/, /e/, /o/ have been controlled since the age of 2 years and 11 months. Previously, he was able to mention the letters $/ \mathrm{a} /, \mathrm{i} / \mathrm{h}$, and $/ \mathrm{u} /$. Furthermore, for consonant letters Juna has mastered some letters, such as /b/, /c/, /d/, /g/, /j/, /m/, /n/, /p/, /q/, /s/, /t/, /w/, and $/ \mathrm{y} /$. For duplicate consonants such as $n y$ and $n g$ have also been dominated by Juna. Here is a consonant table as an illustration of Juna consonant acquisition.

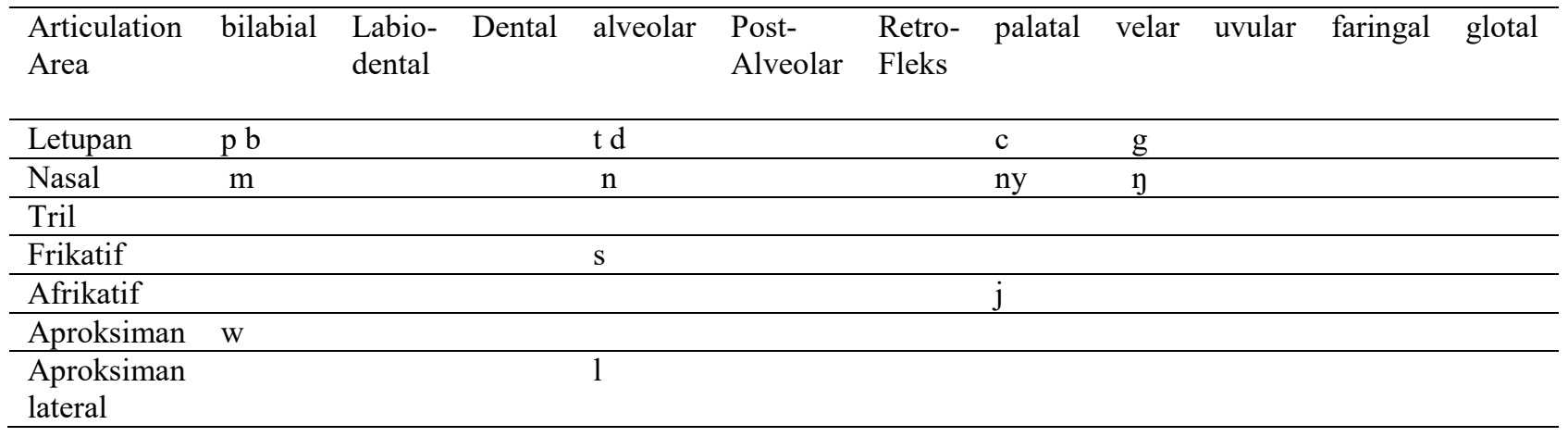

Generally, based on 5 vowels, 21 consonants and 4 consonants such as $n g, n y, k h$, sy, in Indonesian, Juna controls 5 vowel letters, 14 consonants, and 3 double consonants, $n y, n g$, and $s y$. The sounds that have not been mastered, including / $\mathrm{f} / \mathrm{h} / \mathrm{h} / \mathrm{g} / \mathrm{k} /, / \mathrm{r} /, / \mathrm{v} /, / \mathrm{x} /$, and $/ \mathrm{z} /$. The sound $/ \mathrm{x} /$ and $/ \mathrm{z} /$ does not have any difference with the sound / $\mathrm{s} /$. The sound / $\mathrm{f} /$ and / v / changed the sound to / p /. The sound / h /, / k/, and / $/$ / has not yet appeared.

If referring to L. Nicolosi, E Hariman, J. Kresheck (2014) theory should be able to produce a sound / b /, / d /, / h /, $/ \mathrm{m} /, / \mathrm{n} / \mathrm{l} / \mathrm{p} / \mathrm{,} / \mathrm{f} / \mathrm{l} / \mathrm{g} /, / \mathrm{k} /, / \mathrm{t} / \mathrm{,} / \mathrm{w} /$ for the beginning of a word. / f /, / g /, / k /, / ng /, / p /, / t / for the letter in the

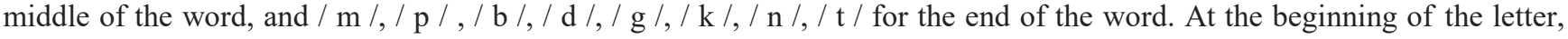
Juna was able to pronounce words, such as $\boldsymbol{d} a . . d a . ., \boldsymbol{m a m a}$, nasi, pipi, gigi, and tutup. It means that from 11 early phonetic sounds that should be mastered by children ages 2 to 3, Juna only controls 7 phonetic sounds among them. The sounds like, $/ \mathrm{h} /, / \mathrm{f} /, / \mathrm{k} /$, and / $\mathrm{w} /$ have not been mastered. Words that represent the letters are meant, haus for the letter / h / at the beginning has not been mastered. The word foto for / f / has not been mastered, kakak for the letter / $\mathrm{k} / \mathrm{has}$ not been 
mastered yet. The word for the / w / has not yet been mastered. Juna exclaimed in a worn-out word, poto for foto, a a for kakak, and for a while. However, in addition to the 11 fonetic letters Juna is also able to excite the word cica 'cicak' for the letter / $\mathrm{c} /$ in the beginning of the sentence.

Furthermore, As for the sound of the letter in the middle of the word that has been mastered Juna, namely mama, $m o b i$ 'car', gig $i$ 'teeth', nging $i$ 'cold', topi hate, pitu 'door'. Based on 9 phonetic sounds that should have been able to be mastered by children ages 2 to 3, Juna only mastered 6 phonetic sounds in the middle of the word. For the letter / n /, / f /, / $\mathrm{k} /$ in the middle of the word has not been mastered. Unclear words are clearly articulated, such as the word pintu 'door"e Juna said the word pitu for ,door ${ }^{e e}$ so that the letter / n / in the middle of the word has not appeared. Furthermore, the word or name of Nifa is proclaimed Juna to be Nipa so that perceives the sound of the letter / f / into / p /. Kakak said to be /a a/. No letter / $\mathrm{k} /$ sounds at all.

At the sound of the end of the word, Juna controls the sounds / p / and / t / only of 8 sounds: / m /, / p /, / b /, / d /, / $\mathrm{g} /, / \mathrm{k} /, / \mathrm{n} /, / \mathrm{t} /$. As for the word that indicates the sound at the end, such as the seperti tutup, imut and imut , In addition to the sound, Juna controls the sound / s / at the end of the word, such nanas and tas although theoretically letters / s / acceptable if controlled by the child at the age of 5 years. However, for the duplicate consonant / ng / at the end of the word has not been mastered. The word is abang be aba. Similarly, the letter / 1 / end of the word bata for bantal, the pillow has not been mastered. It is still acceptable until the age of 5 years.

\section{Morphological Acquisition}

In the morphological aspect, some of the types of words can already be mastered. However, of the 8 types of words in phonology, Juna is able to produce four types of words. Some words are still not clear in articulation. The types of words that have been mastered, such as (1) verbs, (2) nouns, (3) adjectives, and (4) adverbs. In addition, the word form aspect, of the 5 word forms, 2 has been mastered. The form of the word, such as (1) the base and (2) the word again while the combination of words, shortening, and absorption have not been able to express.

The verb that Juna has mastered are 9 words. The word, namely miyum 'drink', siap 'already', uis 'wrote', dudu 'sit', mau „want', tutup ,close , ambi 'take', icu 'follow', angis 'crying'. Nouns that have been mastered amounted to 36 words. As for those words, are uma 'home', jeela 'windows' pitu 'door', tas ,bag', aju 'clothes', ana 'trousers', ue 'cake', usus 'milk', opi 'coffee bata 'pillow', imut 'blanket', ama 'bedroom', katu 'card', panas ,hat', aisim ,ice cream', oka 'chocolate', pisa 'banana', eyi 'strawberry', magis 'mangosteen, aya 'papaya', abe 'chiliee, toma 'tomato', jagu 'corn', wote 'carot', ote 'doctor',yuyu 'guru', posi 'policee.

Furthermore, adjectives that have been mastered a number of 14 words. Those words, the mayu 'shame', edi 'sad', maya 'angry', tatut 'fear', ilau 'glare, eya' red ', tuni 'yellow', ijau ,green', biyu' blue ' itam 'black', puti 'white', unyu 'purple', oka 'chocolate', ping 'pink'. The type of adverb that Juna has mastered a number of sana 'there' dan sini 'here'. Based on the basic word form that has been mastered a number of 11 words, such as apal 'hungry', mai 'play', bitsa 'can', matsu 'in', sleep 'tidu', tida 'no', ya 'yes' ', pipis '(pee pee), ee' eek '(pup). Furthermore, the re-word that has been mastered, such as the repeated word of the butterfly is pu-pu, and kite is aya-aya. There are 2 repeat words, but the pseudonymous categories only have been mastered. There are also words that Juna said in English for 13 words, such as yes 'yes', no 'no', yed 'red', low 'yellow', gri 'green', pepe 'purple', wens 'orange', blu 'blue', bek 'black', and wait 'white', wan 'one, tu „two ', ti ,three ${ }^{e e}$.

Based on several categories of words and forms of words obtained by Juna, there are 85 words that Juna has obtained. Of the 85 words that can be said, 13 word in English. Words said by Juna not all are articulated clearly. Supposedly, children aged 36 months or 3 years old have had vocabulary of 200-300 words. This is in accordance with Barret's statement in Gleason and Ratner (1998: 358) states that children begin to produce the word around the age of 1 year. Age 18-20 produces 50 words. Furthermore, the age of 18-20 months has mastered 200-300 words. That is, Juna should be able to produce words over 200-300 words. That is, Juna's vocabulary is less than 1 year from his age.

\section{Acquisition of Syntax}

Based on the observation results, Juna does not have the skills to compose words into sentences according to his age yet. Forms of expressions are 3 request sentences, 2 sentence commands, 2 invitation of sentences, 2 sentence of statements, 2 sentence of questions. At the age of 3, Juna can make a simple request with S P O elements such as Bu, Juna mau usus 'Bu, Juna mau susu', Bu, Juna mau mai 'Bu, Juna mau main', Bu, Juna mau ue 'bu, juna mau kue'. The key sentence that Juna recently tried to express was his desire for something. The pattern is the same. The difference is the desired object. The command line that Juna got, namely Huuss, gi! 'Huus, pergi!' This sentence is commonly used by Juna in 2 cases. Firstly, he told me when there was a cat on the yard with the aim of kicking off a cat who was fighting a fellow cat in the yard. In addition, when he was defecating at a certain angle at home. Usually, he will expel his mother or father 
who sees his expression being defecated in diapers. Second sentence, uup! 'tutup!. This sentence is usually expressed by Juna when asking the closest people usually mother and father to close the door, toilet door, and car door. Next, an invitation sentence that Juna can pronounce in the form of Ayo, Ibu! ,Ayo, Ibu! ${ }^{\text {le }}$ and Ayo, Ayah! ,Ayo, Ayah . These two sentences are usually expressed by Juna when inviting her parents to play, study, and go out. The 2 sentence statements that Juna often say is the phrase "Da .. da .. Ibu" 'da..da .. Ibu' and $d a$.. da .. Ayah. Ti-ti 'da..da .. Ayah. Hati-hati'. These two sentences were exhaled by Juna when she separated from her father and mother when Mom's mother would work. Next, two sentence questions that Juna has earned in the form of "oe? 'Boleh?" This sentence was filed by Juna when he asked permission to open his own property. The next sentence is Ma Ayah? 'Di mana Ayah?' This sentence was delivered by Juna when asked about his father's presence. This sentence appears when he searches for his father at home but is not seen by Juna. In addition, this sentence also asked when his father had not returned to work.

The acquisition of phonology, morphology, and syntax is known to be incompatible with the age of the child should be. At the beginning of the 24 month Juna was not able to say one word. He is only able to pull his hand or show something he wants. If asked for the imitation of the word we asked for, he did not want. Cry and get mad. He was able to pronounce words from the age of 33 months. Based on a 1 year observation, Juna is able to understand the orders, calls, calls from others. However, it is difficult to express wishes through words. Case of Juna include "language disorders of subcortical motor affasia language disorder or expressive languange disorder". Children tend not to be able to issue words. However, the notion of verbal and visual language is not disturbed and visual expression is running normally during the process of observation of Juna language acquisition. He does have difficulty in concentration and minimal of focus. So that juna needs good help from pediatricians, therapists, and psychologists. This is to catch up with Juna language acquisition with the child's age should be. Juna language disorder is experienced because of the minimal stimulation of the environment. This is referred to in the opinion of Chaer (2010, p. 148) which states that language disorders can result from two factors, namely (1) medical factors and (2) social environmental factors. Juna does not experience hearing loss and also does not experience clinical disturbances such as in children syndrome down, celebral palsy, and others.

\section{CONCLUSION AND RECOMMENDATION}

During the 12 months of observation, Arjuna had a little vocabulary to spell out words like those of Juna's age. Theoretically, should the child 2-3 years have had a vocabulary of approximately 200-300 words. The phonological aspect is obtained by the control of 5 vowels, 14 consonants, and 3 double consonants, are ny, ng, and sy, morphological aspects there are 59 morphemes (both whole and partial morphemes). From syntactic aspect, Arjuna is only able to produce sentences, such as 3 sentence requests, 2 sentence commands, 2 sentence solicitation, 2 sentence statements, 2 sentence questions. Arjuna cases include children who suffer from language disorders of subcortical motor affasia language disorder or expressive languange disorder. Children tend not to be able to issue words. However, the notion of verbal and visual language is not disturbed and visual expression is running normally. The child has not been able to produce speech in the form of a word even though he understands the meaning of the speech of the other person, the opponent's command, the request of the other person, and the like. It is reviewed based on the number of vocabularies possessed and the imperfect articulation. The causes of speech delays are caused by environmental factors, such as lack of stimulus when the baby is exposed to visual television, and gadgets so it needs to be followed up through medical help, such as specialist child growth doctors, psychologists, and therapists.

\section{Reference}

Arsanti, M. (2014). "Pemerolehan Bahasa pada Anak: Kajian Psikolinguistik". Jurnal PBSI, 3(2): $24--47$.

Chaer, A. (2003). Psikolingustik: kajian teoritik. Jakarta: PT Rineka Cipta.

Cummings, L. (2008). Clinical linguistic. USA: Edinburgh University Press.

Cummings, L. (2010). Pragmatik klinis kajian tentang penggunaan dan gangguan bahasa secara klinis. Yogyakarta: Pustaka Pelajar.

Dardjowidjojo, S. (2010). Psikolinguistik: pengantar pemahaman bahasa manusia. Jakarta: Yayasan Obor Indonesia. Kushartanti, U. dan Multamia. (2005). Pesona bahasa: langkah awal memahami linguistik. Jakarta: GPU. Suroso, E. (2016). Psikolinguistik. Yogyakarta: Penerbit Ombak.

Gleason, J. B. \& N. B. Ratner. (1998). Psycholinguistics (second edition). Orlando: Harcourt Brace College Publishers.

L. Nicolosi, E. Harryman, \& J. Kresheck. (2004). Terminology of communication disorders: speech learning-hearing. Baltimore.

Tsujinmura, N. (1997). An introduction to japanese linguistics. USA: Blackwell Publishers.

Spiliotopoulou, V. (2009). Expressive language disorder and how it connects with mood and behavior disorder. Pennsylvania: University of Pittsburgh. 